\title{
Economic Learning during The Covid-19 Pandemic in Indonesia: Problems and Solutions
}

\author{
Leny Noviani \\ Universitas Sebelas Maret \\ lenynoviani@staff.uns.ac.id
}

\section{Article History}

accepted 31/01/2021

approved 28/02/2021

published 31/03/2021

\begin{abstract}
The purpose of this study is to provide alternative solutions to problems in implementing economic learning during the Covid-19 pandemic in Indonesia. This research uses a descriptive approach. Data collection was conducted through a survey of 296 economics teachers who teach in senior high school. Data analysis using descriptive analysis. The results showed the main problems faced by economics teachers during the pandemic were: unstable internet network quality, difficulties in preparing media, teaching materials, and developing assessments. Activities undertaken by the teacher to overcome these problems include: using the WhatsApp application for teaching, searching for teaching materials and media from internet sources, using student worksheets in student handbooks. Alternative solutions to overcome the constraints of implementing economic learning during the pandemic are: 1) designing combined online learning using a digital platform that is easily accessible to students, 2) developing media, teaching materials and evaluations that are in accordance with real conditions so that learning remains meaningful for students and can equip students with life skills, 3) optimization of teacher working groups in schools to develop learning strategies, media, teaching materials and evaluation.
\end{abstract}

Keywords: economic learning, covid-19 pandemic

\begin{abstract}
Abstrak
Tujuan dari penelitian ini adalah untuk memberikan alternatif pemecahan masalah dalam pelaksanaan pembelajaran ekonomi pada saat pandemi Covid-19 di Indonesia. Penelitian ini menggunakan pendekatan deskriptif. Pengumpulan data dilakukan melalui survei terhadap 296 guru ekonomi yang mengajar di SMA. Analisis data menggunakan analisis deskriptif. Hasil penelitian menunjukkan masalah utama yang dihadapi guru ekonomi selama pandemi adalah: kualitas jaringan internet yang tidak stabil, kesulitan dalam menyiapkan media, bahan ajar, dan mengembangkan penilaian. Kegiatan yang dilakukan oleh guru untuk mengatasi permasalahan tersebut antara lain: menggunakan aplikasi WhatsApp untuk pembelajaran, mencari bahan ajar dan media dari sumber internet, menggunakan LKS pada buku pegangan siswa. Alternatif solusi untuk mengatasi kendala pelaksanaan pembelajaran ekonomi pada masa pandemi adalah: 1) merancang pembelajaran daring kombinasi dengan menggunakan platform digital yang mudah diakses siswa, 2) mengembangkan media, bahan ajar dan evaluasi yang sesuai dengan kondisi nyata sehingga pembelajaran tetap bermakna bagi siswa dan dapat membekali siswa dengan kecakapan hidup, 3) optimalisasi kelompok kerja guru di sekolah untuk mengembangkan strategi pembelajaran, media, bahan ajar dan evaluasi.
\end{abstract}

Kata kunci: pembelajaran ekonomi, pandemi Covid-19

Social, Humanities, and Education Studies (SHEs): Conference Series https://jurnal.uns.ac.id/shes

p-ISSN 2620-9284 e-ISSN 2620-9292 


\section{PENDAHULUAN}

Sejak awal Maret 2020, pemerintah Indonesia mengeluarkan kebijakan pembatasan interaksi sosial untuk memutus penyebaran virus Covid-19. Salah satu kebijakan pemerintah adalah dengan melakukan penutupan sekolah-sekolah sehingga pembelajaran dilakukan melalui pembelajaran virtual. Pembelajaran di semua jenjang pendidikan dilakukan dengan menggunakan platform digital. Pembelajaran dengan menggunakan komunikasi dan aplikasi digital memiliki tantangan tersendiri bagi guru dan siswa (McLoughlin \& Lee, 2010). Guru dan siswa mengalami kesulitan dan tantangan yang belum pernah terjadi sebelumnya saat pembelajaran dilakukan secara tatap muka. Pembelajaran secara online menggunakan teknologi yang menawarkan komunikasi secara cepat dan menuntut umpan balik secara instan (Charlton, J. J., \& Law, 2014).

Dalam pembelajaran daring, guru harus menuangkan pembelajaran konvensional menjadi pembelajaran dalam bentuk digital (Imania \& Bariah, 2019). Hal ini tentunya juga dirasakan oleh seluruh guru ekonomi yang mengajar di sekolah menengah atas. Guru ekonomi biasanya dalam penggunaan media pembelajaran menggunakan pengajaran secara langsung menggunakan papan tulis untuk menjelaskan konsepkonsep teori ekonomi menggunakan gambar, kurva/grafik, bagan termasuk prosedur menggunakan rumus. Sedangkan pada saat pandemi ini, guru ekonomi harus menggunakan paltform digital untuk mengubah media ataupun strategi pembelajaran menjadi media berbasis digital. Perubahan inilah yang menjadi kendala bagi guru dalam melaksanakan pembelajaran (Noviani et al., 2020). Pendekataan pembelajaran yang mengkombinasikan pembelajaran online dengan pembelajaran tatap muka lebih baik hasilnya (Aspden, L., \& Helm, 2004). Namun pembelajaran semacam itu tidak mungkin dilakukan saat pandemic Covid-19.

Pemerintah telah menginstruksikan bahwa kegiatan Belajar dari Rumah melalui pembelajaran daring/jarak jauh dilakukan untuk memberikan pengalaman belajar yang bermakna bagi siswa, tanpa harus menuntaskan seluruh capaian kompetensi sesuai dengan kurikulum untuk tujuan kenaikan kelas ataupun kelulusan namun pembelajaran difokuskan pada pendidikan kecakapan hidup. Degan demikian, pembelajaran ekonomi selama pandemi perlu di desain membekali kecakapan hidup dengan mengkaitkan materi yang sesuai dengan tuntutan kurikulum. Kecakapan hidup merupakan kecakapan yang diperlukan oleh seseorang dalam kehidupannya (Asmani, 2009; Brolin, 1989; Kunandar, 2009).

Kendala pembelajaran daring dalam pelaksanaannya antara lain: infrastruktur jaringan internet yang tidak stabil, kendala teknis seperti server down, listrik padam ketika mengakses pembelajaran online, komitmen orang tua yang tidak mendukung, partisipasi siswa dalam proses pembelajaran kurang, dan motivasi siswa yang tidak menentu, dan kemampuan pengajar yang belum memadai (Dong, 2020; Dursun et al., 2013; Nurmukhametov et al., 2015). Kendala tersebut dirasakan hampir sebagian guru, baik guru sekolah dasar sampai guru sekolah menengah atas. Semua guru pada saat pandemi ini harus menyesuaikan perubahan dari pembelajaran tatap muka di sekolah dengan bentuk pembelajaran dengan menggunakan platform digital.

Pembelajaran online yang saat ini dilakukan semua guru merupakan alternatif untuk mengatasi situasi kritis (Wang, G., Zhang, Y., Zhao, J., Zhanh, J., \& Jianh, 2020) yang tetap harus mempertimbangkan efektivitas pembelajaran. Sekolah harus memperhatikan beberapa hal agar pembelajaran online saat pandemi tetap berjalan dengan baik yaitu: interaksi siswa, infrastruktur yang dibutuhkan, kemampuan personal 
(guru), pemenuhan kebutuhan untuk belajar, kesulitan yang dirasakan oleh siswa dan guru, dan umpan balik (Hodges, C., Moore, S., Lockee, B., Trust, T., \& Bond, 2020)

Oleh karena itu, pelaksanaan pembelajaran perlu mengintegrasikan unsur-unsur life skills, namun kenyataanya pembelajaran di sekolah cenderung sangat teoritik dan tidak terkait dengan lingkungan siswa (Blazely, 1997). Penelitian ini mendeskripsikan hambatan atau permasalah yang dihadapi guru ekonomi selama pandemi Covid-19. Lebih penting lagi, penelitian ini mengajukan alternatif solusi untuk memecahkan masalah terkait dengan pelaksanaan pembelajaran ekonomi selama pandemi.

\section{METODE}

Penelitian ini menggunakan pendekatan deskriptif. Pengumpulan data dilakukan melalui survey kepada 296 guru ekonomi sekolah menengah atas yang tersebar di Provinsi DKI Jakarta, Jawa Barat, Jawa Tengah, Jawa Timur, Bengkulu, Lampung, Sumatera Barat, Riau, Kalimantan Tengah, Maluku, Sulawesi Selatan, Sulawesi Tengah, Nusa Tenggara Timur. Survey dilakukan untuk menjaring informasi mengenai pelaksanaan pembelajaran ekonomi selama pandemi Covid-19. Data yang terkumpul, dianalisis dengan menggunakan analisis deskriptif. Studi literatur dilakukan dengan mencari dan mempelajari referensi yang relevan untuk menemukan alternatif solusi masalah pembelajaran daring pada mata pelajaran ekonomi.

\section{HASIL DAN PEMBAHASAN}

Profil responden dalam penelitian ini adalah sebagai berikut:

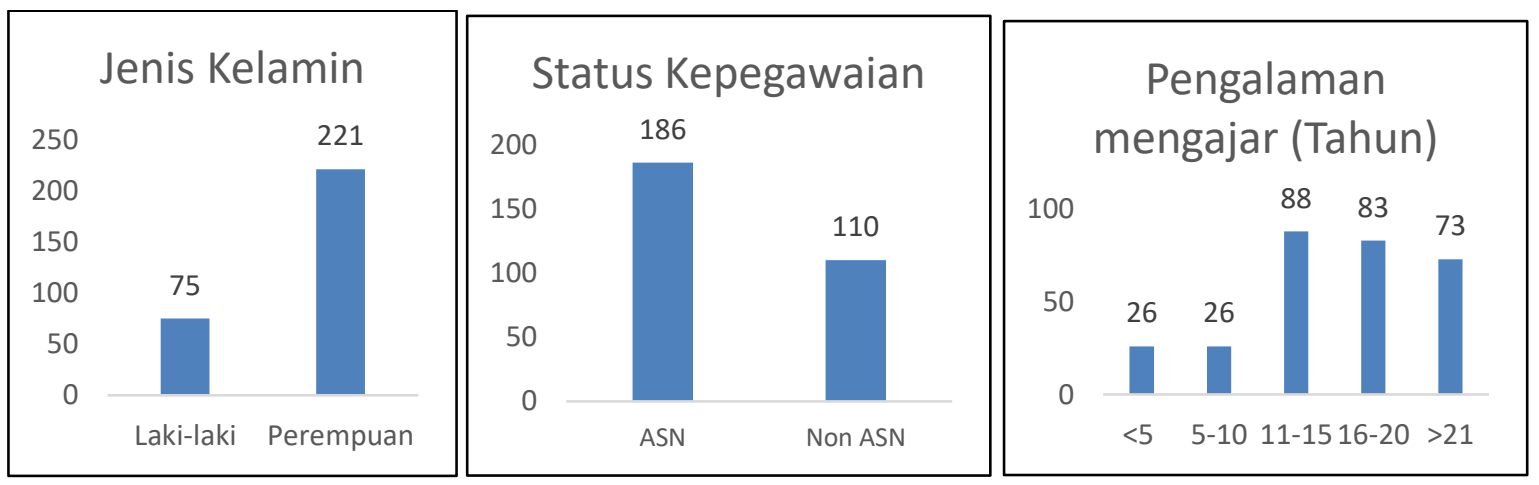

Gambar 1. Profil Responden

Guru ekonomi dihadapkan pada tantangan dan kendala dalam pelaksanaan pembelajaran online. Kesulitan yang belum pernah terjadi sebelumnya meliputi penggunaan media, pemilihan materi, pelaksanaan penilaian, dan pemantaun perkembangan siswa. Implementasi kebijakan belajar dari rumah dan bekerja dari rumah, mengharuskan guru ekonomi dan siswa menggunakan berbagai platform digital untuk melaksanakan pembelajaran. Platform digital yang paling banyak digunakan oleh guru Ekonomi di Indonesia selama pandemi Covid-19 adalah aplikasi WhatsApp, google classroom, zoom dan google meet. 


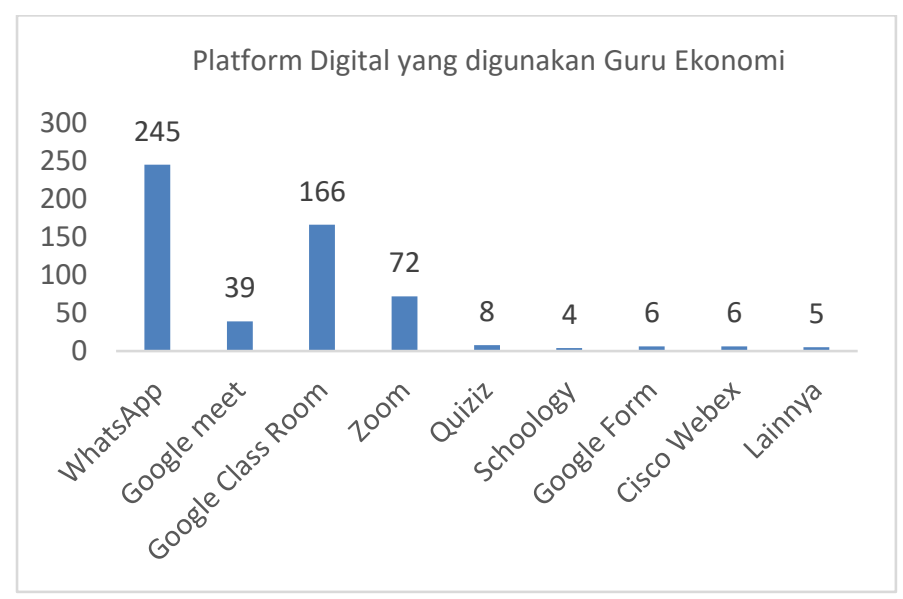

Gambar 2. Paltform Digital yang digunakan oleh Guru Ekonomi

Responden dapat memilih beberapa aplikasi yang digunakan selama pembelajaran online. Aplikasi WhatsApp pada saat situasi pandemi Covid-19 menjadi aplikasi yang banyak digunakan oleh guru. Sebanyak 245 orang guru ekonomi menggunakan aplikasi ini. Aplikasi lain yang banyak digunakan adalah google class room. 166 orang dari seluruh responden menggunakan aplikasi google class room. Beberapa sekolah menetapkan kebijakan penggunaan salah satu aplikasi untuk melakukan pembelajaran online. Aplikasi lain yang digunakan guru ekonomi secara berututan adalah: aplikasi zoom meeting, google meet, quiziz, google form, ciscco webex, schoology. Sebagian besar guru ekonomi menggunakan kombinasi platform digital, namun aplikasi WhatsApp yang paling sering digunakan. Aplikasi WhatsApp digunakan untuk mengunggah materi dalam bentuk bahan tayang maupun teks, mengunggah video pembelajaran $(41,2 \%)$, dan sebagai sarana menyampaikan tugas sesuai kurikulum $(58,8 \%)$.

\section{Kendala}

Kendala yang dirasakan oleh guru Ekonomi dalam mempersiapkan pembelajaran online berdasarkan urutannya: 1) kurangnya kemampuan dalam mengembangkan media, 2) kesulitan membuat bahan ajar yang memadai, 3) kesulitan mengembangkan instrumen penilaian. Sebanyak 49,3\% guru ekonomi merasakan kesulitan dalam mengembangkan media pembelajaran. Sebanyak $27,7 \%$ guru mengalami kesulitan dalam mengembangkan materi atau bahan ajar. Sebanyak $23 \%$ guru ekonomi merasakan kesulitan dalam mengembangkan instrument penilaian khususnya aspek psikomotor.

Kendala yang dirasakan oleh guru Ekonomi dalam pelaksanaan pembelajaran online adalah:1) jaringan internet yang tidak memadai dan tidak stabil, 2) keterlibatan siswa dalam pembelajaran rendah, 3) siswa sulit memahami beberapa materi ekonomi, 4) cakupan materi kurang memadai sehingga tujuan pembelajaran tidak tercapai. Kendala kualitas jaringan yang tidak stabil bahkan kurang memadai mengharuskan guru maupun siswa harus pergi ke tempat lain untuk memperoleh jaringan internet selama pembelajaran online. Sebanyak $71,3 \%$ guru menyatakan bahwa kendala utama pembelajaran selama pandemic adalah kualitas jaraingan yang kurang baik. Kualitas jaringan yang tidak stabil akan menyebabkan tujuan pembelajaran maupun 
interaksi antara guru dan siswa menjadi kurang. Selain kendala jaringan internet, guru ekonomi menyatakan permasalahan terbesar berikutnya adalah keterlibatan siswa dalam proses pembelajaran rendah $(77,7 \%)$. Hal ini ditunjukkan bahwa selama pembelajaran online yang dilakukan secara sinkronus, kurang dari $10 \%$ siswa yang terlibat baik dalam menjawab pertanyaan guru, menyampaikan gagasan atau ide. Saat pembelajaran melalui asinkronus, tanggapan siswa juga sangat kurang. Selama pembelajaran, siswa tepat waktu melakukan presesensi kehadiran. Dengan demikian, siswa sebenarnya hadir dalam chanel pada platform digital yang digunakan tetapi tidak focus terhadap materi pelajaran yang disampaikan oleh guru. Guru menilai bahwa selama pembelajaran online, siswa sulit memahami materi ekonomi $(67 \%)$ terutama yang memerlukan penjelasan model matematis maupun grafis. Kendala lain yang dirasakan guru ekonomi adalah cakupan materi yang disampaikan sangat terbatas, Guru belum merasakan puas jika tidak menyampaikan semua materi seperti saat pembelajaran tatap muka $(59,3 \%)$. Guru merasa tidak dapat menuntaskan materi sehingga tujuan pembelajaran tidak tercapai.

Kendala yang dirasakan guru dalam melakukan penilaian berdasarkan urutannya adalah: 1) kesulitan mengembangkan penilaian pada aspek psikomotor $(67,6 \%)$, aspek sikap $(62,2 \%)$, dan aspek kognitif $(24 \%), 2)$ membutuhkan waktu cukup banyak untuk memberikan umpan balik terhadap hasil pekerjaan siswa (53\%). Untuk mengukur kemampuan siswa pada aspek pengetahuan, guru menggunakan soal atau pertanyaan yang terdapat di buku teks (85,5\%). Sebanyak $76,4 \%$ guru mengukur kemampuan pemahaman, sedangkan $23,6 \%$ guru mengukur kemampuan menganalisis dan mengevaluasi. Untuk mengukur kemampuan siswa dalam aspek keterampilan, sebanyak 22, 6\% guru memberikan tugas berupa proyek kepada siswa. Sebanyak $85,5 \%$ guru memberikan tugas seperti yang tercantum dalam buku teks, sehingga guru harus memberikan umpan balik terhadap tugas siswa tersebut. Dengan demikian, guru membutuhkan waktu lebih banyak, sehingga banyak guru yang tidak memberikan umpan balik secara detail.

\section{Solusi}

Dalam persiapan pembelajaran secara online, guru mengalami kendala mempersiapkan media, bahan ajar dan instrument penilaiannya. Dengan demikian dapat disimpulkan bahwa guru mengalami kesulitan merancang pembelajaran online yang efektif. Penelitian sebelumnya menunjukkan bahwa guru tidak berdaya atau tidak tahu bagaimana membuat rencana pengajaran dan desain pembelajaran yang baik (Dong, 2020). Perencanaan pembelajaran merupakan proses penyusunan materi pelajaran, penggunaan media, metode pengajaran dan penilaian untuk mencapai tujuan yang telah di tentukan (Majid, 2007). Hal terpenting adalah bagaimana merancang pembelajaran yang melibatkan siswa secara aktif dalam proses pembelajaran. Terjadinya proses belajar pada diri siswa inilah yang menunjukkan keberhasilan (Joyoatmojo, Soetarno., Noviani, Leny., Wahyudi, 2018). Hasil jangka panjang dari sebuah pembelajaran adalah diperolehnya peningkatan kemampuan belajar dan mampu memberikan life skills pada peserta didik (Asmani, 2009; Balasubramanian, K., Jaykumar, V., and Fukey, 2014; Joyce, Bruce., Weil, Marsha., Calhoun, 2009). Hal ini sesuai dengan kebijakan pemerintah bahwa Belajar dari Rumah dilakukan untuk memberikan pengalaman belajar yang bermakna bagi siswa, tanpa harus menuntaskan seluruh capaian kompetensi sesuai dengan kurikulum untuk tujuan kenaikan kelas ataupun kelulusan namun pembelajaran difokuskan pada pendidikan kecakapan hidup. Kecakapan hidup merupakan kecakapan yang diperlukan oleh seseorang dalam kehidupannya (Brolin, 1989; Kunandar, 2009). 
Kecakapan hidup mencakup: kecakapan personal, kecakapan sosial, kecakapan akademik, dan kecakapan vokasional (Education, 2018). Oleh karena itu, pelaksanaan pembelajaran perlu mengintegrasikan unsur-unsur life skills, namun kenyataanya pembelajaran di sekolah cenderung sangat teoritik dan tidak terkait dengan lingkungan siswa (Blazely, 1997). Begitu pula saat pembelajaran daring, guru masih fokus pada pencapaian tuntutan kompetensi pada kurikulum.

Dalam pelaksanaan pembelajaran ekonomi, kecakapan tersebut tidak dapat berdiri sendiri-sendiri, namun menjadi satu kesatuan yang tergambar dalam proses pembelajaran mulai dari awal sampai akhir pembelajaran. Oleh karena itu, seorang guru perlu memiliki kemampuan dalam merencanakan, melaksanakan, dan mengevaluasi pembelajaran (Nasuiton, 2003). Kemampuan merencanakan pembelajaran merupakan kemampuan dasar yang harus dimiliki guru. Perencanaan pembelajaran yang baik terdiri dari: 1) tujuan pembelajaran, 2) materi pembelajaran, bahan ajar, pendekatan dan metode, media pengajaran, pengalaman belajar, dan 3) evaluasi keberhasilan (Gagne , R.M., \& Briggs, 1979). Dalam mempersiapkan pembelajaran ekonomi selama pandemi, guru harus merancang pembelajaran yang dapat mengintegrasikan nilai-nilai life skills, mengembangkan pembelajaran yang dapat melibatkan siswa berinteraksi atau terlibat aktif dalam proses pembelajaran. Perencanaan langkah pembelajaran lebih diarahkan pada pemanfaatan lingkungan sekitar siswa dengan pendekatan kontekstual, pengalaman siswa dan lingkungan sekitar menjadi media sekaligus sebagai bahan ajar yang lebih bermakna. Penelitian sebelumnya membuktikan interaksi antar siswa, interaksi siswa dan guru adalah faktor paling penting yang mendukung keberhasilan siswa dalam belajar secara online (Moore, M., \& Kearsley, n.d.; Swan, 2002)

Dalam pelaksanaan pembelajaran online, untuk mengurangi kebosanan siswa, dapat dilakukan dengan kombinasi pembelajaran daring sinkronus dan asinkronus. Aktivitas siswa di fokuskan pada melatihkan kemampuan higer order thinking skill. Hal ini sejalan dengan temuan penelitian Dong (Dong, 2020)bahwa sebagian besar peserta didik menyatakan bahwa dalam kelas online, guru mengambil kelas dari awal hingga akhir dengan gaya mengajar yang membosankan, isi pengajaran yang kurang beragam sehingga siswa sering merasa jenuh dan mengantuk. Lebih lanjut, (Dong, 2020), menyaranakan solusi menghadapi kesulitan dan tantangan pengajaran online adalah: 1) institusi pendidikan memperhatikan kondisi atau pengalaman yang dialami guru dan siswa selama pembelajaran online, 2) siswa didorong untuk mengambil inisiatif dalam pembelajaran online, 3) adanya komunikasi yang tepat antara guru dan siswa terutama saat siswa mengalami kesulitan, dan memberikan umpan balik, 4) lembaga pendidikan harus menyediakan pelatihan pengajaran online untuk membantu guru membuat desain pembelajaran yang lebih baik serta pelatihan pengoperasian teknis perangkat lunak untuk guru dan siswa demi pengajaran yang lebih efektif.

Berdasarkan data penelitian menujukkan bahwa guru ekonomi melakukan penilaian pada aspek kognitif dengan mengunakan instrumen penilaian yang ada di buku teks ekonomi yang di miliki siswa. Soal tes yang dikembangkan guru lebih dominan mengukur aspek berpikir kognitif level pemahaman (C1-C2). Beberapa guru sebenarnya telah mengembangkan penilaian untuk mengukur kemampuan higer oder thinking skill (C4). Penelitian lain juga menunjukkan bahwa selama pandemi, beberapa dosen jurusan pendidikan bahasa Inggris di Sulawesi Selatan mengukur kemampuan mahasiswa pada skala C1-C2, sedikit dosen yang mengukur pada level C5-C6 (Akib \& Muhsin, 2020). 
Teknik penilaian yang dilakukan guru adalah tes tertulis dengan menggunakan aplikasi seperti google form, quizizz, google class room, maupun mengerjakan secara manual dan di kumpulkan ke sekolah pada waktu yang telah ditentukan. Sebanyak $22,6 \%$ guru ekonomi melakukan penilaian aspek psikomotor dengan cara memberikan penugasan berupa proyek. Dalam pembelajaran berbasis proyek, guru ekonomi memberikan tugas kepada siswa berupa penelitian sederhana terkait dampak pandemi Covid-19 terhadap perekonomian di Indonesia. Siswa ditugaskan untuk mengamati, mencari data dan informasi, menganalisis dan menyusun laporan. Penilaian aspek sikap saat pandemi dirasakan sulit di lakukan oleh guru. Guru hanya melihat absensi siswa setiap pembelajaran ekonomi dimulai dan ketepatan waktu ketika siswa mengumpulkan tugas.

Berdasarkan uraian di atas, dapat disampaikan beberapa alternatif solusi dalam mengatasi permasalahan pembelajaran selama pandemi Covid-19 untuk mata pelajaran ekonomi di sekolah menengah adalah merancang dan melaksanakan pembelajaran ekonomi yang melatihkan kecakapan hidup yaitu kecakapan personal, kecakapan sosial, kecakapan akademik, dan kecakapan vokasional. Guru ekonomi dapat menggunakan pembelajaran berbasis proyek maupun pembelajaran berbasis masalah. Pelaksanaan pembelajaran ekonomi dapat dilakukan dengan mengkombinasikan pembelajaran daring sinkronus dan asinkronus. Dalam pelaksanaan pembelajaran online, guru memperhatikan kesulitan yang dirasakan siswa dalam memahami materi pelajaran dengan mengefektifkan komunikasi dengan siswa. Penilaian yang dilakukan guru tidak hanya dalam skala ingatan dan pemahaman, namun penilaian lebih di fokuskan pada higer oder thinking skills. Salah satu solusi yang dapat dilakukan guru ekonomi adalah dengan pembelajaran berbasis proyek dengan menugaskan siswa melakukan penelitian sederhana. Penelitian sederhana ini dapat melatihkan nilai-nilai life skills kepada siswa. Penugasan tersebut melatih siswa untuk: 1) menggali, menemukan dan mengolah informasi; 2) mengambil keputusan untuk memecahkan masalah; dan 3) menyajikan hasil penelitian melalui media berbasis teknologi informasi. Pembelajaran ekonomi berbasis life skills tidak hanya membantu siswa memahami konsep ekonomi melainkan juga membekali keterampilan yang diperlukan sebagai makluk homoekonomikus yang bermoral dan bermanfaat bagi kehidupannya baik secara pribadi maupun sebagai anggota masyarakat.

Langkah-langkah dalam mengimplementasikan pembelajaran ekonomi yang mengintegrasikan nilai-nilai life skills selama pandemic adalah sebegai berikut:1) menentukan platform digital yang tepat, 2) mengidentifikasikan nilai-nilai life skills apa saja yang penting untuk dilatihkan kepada siswa, 3) merumuskan tujuan pembelajaran, 4) memilih materi, 5) menentukan strategi pembelajaran yang dapat melatihkan life skills kepada siswa dengan mengkombinasikan daring sinkronus dan asinkronus, 6) menentukan media pembelajaran dan sumber belajar, dan 7) mengembangkan penilaian pembelajaran yang mengukur higer order thinking skills. Pemilihan materi pelajaran harus menunjang pencapaian tujuan pembelajaran, sesuai perkembangan siswa, dan mendukung penguasaan pengetahuan siswa akan fakta, konsep, prosedur dan metakognitif. Sumber belajar lebih memanfaatkan lingkungan siswa sehingga pembelajaran menjadi kontekstual. Strategi pembelajaran yang dapat melatihkan life skills antara lain pembelajaran berbasis proyek, inkuiri, ekspositori, kooperatif, kontekstual, dan pembelajaran berbasis masalah. Pemilihan media pembelajaran dalam pembelajaran online perlu memperhatikan kemampuan siswa baik terkait ketersediaan sarana untuk melakukan pembelajaran online, dan juga kemampuan siswa dalam menggunakan teknologi digital. Penilaian yang dapat mengimplementasikan life skills dapat berupa penilaian proyek, produk, dan portofolio. 
Tidak kalah pentingnya, kepala sekolah dan pembuat kebijakan Pendidikan menyelenggarakan pelatihan pemanfaatn aplikasi atau platform digital secara berkelanjutan mulai sosialisasi, training, pendampingan dan monitoring.

\section{SIMPULAN}

Pemanfaatan berbagai platform digital dapat dipilih sebagai media pembelajaran secara online, namun demikian perlu memperhatikan kendala-kendala yang dialami siswa karena perbedaan kemampuan mengakses pembelajaran dan ketersediaan sarana prasarana. Perencanan pembelajaran online yang baik menjadi kunci keberhasilan pelaksanaan pembelajaran. Perencanaan pembelajaran meliputi: 1) pemilihan platform digital yang tepat, 2) identifikasi nilai-nilai life skills, 3) merumuskan tujuan pembelajaran, 4) memilih materi, 5) menentukan strategi pembelajaran yang dapat melatihkan life skills kepada siswa dengan mengkombinasikan pembelajaran daring sinkronus dan asinkronus, 6) menentukan media pembelajaran dan sumber belajar, dan 7) mengembangkan penilaian pembelajaran yang mengukur higer order thinking skills (penilaian proyek, produk, portofolio). Pembelajaran ekonomi selama masa pandemic tetap memperhatikan pencapaian tujuan kurikulum namun lebih penting membekali siswa life skills dengan menggunakan pembelajaran berbasis masalah, inkuiri, ekspositori, kooperatif, dan pembelajaran kontekstual. Pembelajaran ekonomi dengan memanfaatkan lingkungan sekitar siswa sebagai sumber belajar akan lebih bermakna bagi siswa. 


\section{DAFTAR PUSTAKA}

Akib, E., \& Muhsin, M. A. (2020). Critical thinking in cognitive domain: Exploring assessment of English teaching at pandemic period of covid-19. JEES (Journal of English Educators Society), 5(2), 178-184. https://doi.org/10.21070/jees.v5i2.752

Asmani, J. M. (2009). "Sekolah Life skillss" Lulus Siap Kerja (1st ed.). Diva Press.

Aspden, L., \& Helm, P. (2004). Making the connection in a blended learning environment. Educational Media International, 3, 245-252. https://doi.org/10.1080/09523980410001680851

Balasubramanian, K., Jaykumar, V., and Fukey, L. N. (2014). Balasubramanian, K., Jaykumar, V., and Fukey, L. N. Procedia - Social and Behavioral Sciences, 144, 416-422. doi: 10.1016/j.sbspro.2014.07.311

Blazely, L. (1997). Science Study. The Grand Japan Foundation.

Brolin, D. (1989). Life Centered Career Education: A. Competency, Based Approach Reston VA. The Council for Exeptional University.

Charlton, J. J., \& Law, J. (2014). The Story in a Box': measuring the online communication behaviours of children identified as having emotional and behavioural difficulties using LENA and Noldus Observer. Emotional and Behavioural Difficulties, 19(1), 41-58. https://doi.org/10.1080/13632752.2013.854957

Dong, J. (2020). Online Learning and Teaching Experiences During the COVID-19 Pandemic: A Case Study of Bangladeshi Students Receiving China's Higher Education. English Linguistics Research, 9(2), 37. https://doi.org/10.5430/elr.v9n2p37

Dursun, T., Oskaybaş, K., \& Gökmen, C. (2013). The Quality Of Service Of The Distance Education. Procedia - Social and Behavioral Sciences, 103, 1133-1151. https://doi.org/10.1016/j.sbspro.2013.10.441

Education, T. B. B. (2018). Pendidikan Berorientasi Kecakapan Hidup (Life skills Education) Buku 1. Depdiknas.

Gagne , R.M., \& Briggs, L. J. (1979). Principle of Instructional Design. Holt Rinehart and Winston.

Hodges, C., Moore, S., Lockee, B., Trust, T., \& Bond, A. (2020). The difference between emergency remote teaching and online learning. Educause Review. https://er.educause.edu/articles/2020/3/the-difference-between-emergencyremote-teaching-andonline-learning

Imania, K. A., \& Bariah, S. K. (2019). Rancangan Pengembangan Instrumen Penilaian Pembelajaran Berbasis Daring. Jurnal Petik, 5(1), 31-47. https://doi.org/10.31980/jpetik.v5i1.445

Joyce, Bruce., Weil, Marsha., Calhoun, E. (2009). Models of Teaching. Pustaka Pelajar.

Joyoatmojo, Soetarno., Noviani, Leny., Wahyudi, S. (2018). Strategi Pembelajaran. UNS Press.

Kunandar. (2009). Guru Profesional Implementasi Kurikulum Tingkat Satuan Pendidikan (KTSP) dan Sukses dalam Sertifikasi Guru. Raja Grafindo Persada.

Majid, A. (2007). Perencanaan Pembelajaran: Mengembangkan Standar Kompetensi Guru. Remaja Rosdakarya.

McLoughlin, C., \& Lee, M. J. W. (2010). Personalised and self regulated learning in the Web 2.0 era: International exemplars of innovative pedagogy using social software. Australasian Journal of Educational Technology, 26(1), 28-43. https://doi.org/10.14742/ajet.1100

Moore, M., \& Kearsley, G. (n.d.). Moore, M., \& Kearsley, G. (2005). Distance education: A systems view. Thomson Wadsworth.

Nasuiton. (2003). Berbagai Pendekatan dalam Proses Belajar Mengajar. Bumi Aksara. 
Noviani, L., Sabandi, M., (2020). PEMBELAJARAN EKONOMI BERBASIS LIFE SKILLS SEBAGAI SOLUSI PADA SITUASI PANDEMI COVID-19. Seminar Nasional: Strategi Pembelajaran Inovatif Era Merdeka Belajar dan New Normal Berbasis Digital: 99-105.

Nurmukhametov, N., Temirova, A., \& Bekzhanova, T. (2015). The Problems of Development of Distance Education in Kazakhstan. Procedia - Social and Behavioral Sciences, 182, 15-19. https://doi.org/10.1016/j.sbspro.2015.04 .729

Swan, K. (2002). Building learning communities in online courses: The importance of Interaction. Education, Communication \& Information, 2(1), 23-49. https://doi.org/10.1080/1463631022000005016

Wang, G., Zhang, Y., Zhao, J., Zhanh, J., \& Jianh, F. (2020). Mitigate the effects of home confinement on children during the COVID-19 outbreak. The Lancet, 395(10228), 21-27. https://doi.org/10.1016/S0140-6736(20)30547-X 